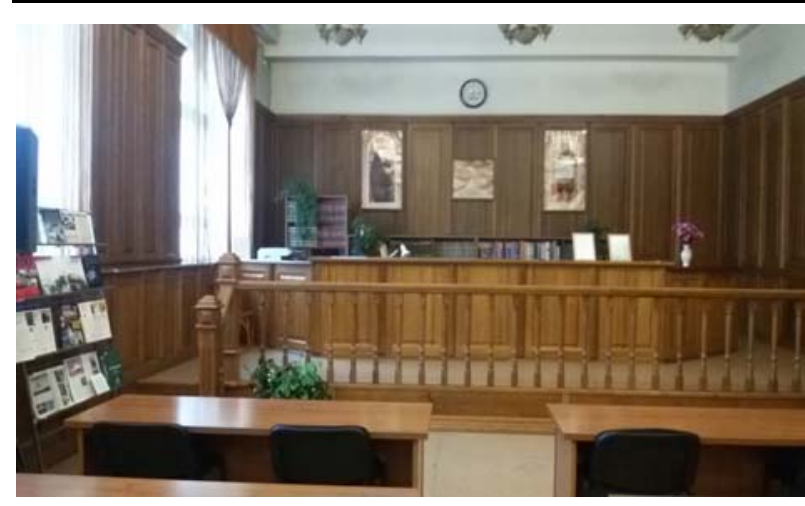

Читальный зал ЦГБ им. В. М. Шукшина г. Бийска

«игру» размеров и форм небольших дверок, создающую привлекательную атмосферу уютного «домашнего» интерьера.

К сожалению, реконструкция-реставрация памятника архитектуры «Торговый дом А. В. Осипова» для Центральной городской библиотеки им. В. М. Шукшина в городе Бийске была приостановлена в 2009 году из-за отсутствия финансирования.

Закономерно, что для редких, уникальных объектов, угроза утраты их самих и их ценностных свойств наиболее велика. Проблема охраны библиотечного архитектурного наследия связана с проблемой охраны того информационного потенциала, который содержат их фонды. Поэтому реконструк- ция или реставрация библиотек становится крайне сложной, определяемой многими факторами.

\section{Список литературь}

1. Кроллер $\Phi$. Применение стандартов при строительстве библиотек в Австрии // Библиотековедение и библиография за рубежом. 1985. № 94. C. 25-28.

2. Бермилеева А. Ни шатко, ни валко // Библиотекарь. 1990. № 1. С. 28-29.

3. Беплер Й. Строительство нового здания для соборной библиотеки в Хильдесхейме // Петербургская библиотечная школа. 1998. № 3/4. С. 45-51.

4. Ястребова Е. М. Красиво, современно, технологично: архитектура и дизайн немецких библиотек // Научные и технические библиотеки. 1994. № 3. С. 59-63.

5. Куликова Л. В., Могилевер Н. В. Организационно-технологический проект реконструкции библиотеки Алвара Аалто г. Выборга Ленинградской области // Петербургская библиотечная школа. 1998. № 3/4. С. 68-95.

6. Бийск, Бийский район. Памятники истории и культуры. Бийск, 1992. 119 с.

7. Степанская T. М. Архитектура и искусство // История Алтая : [в 3 т.]. Т. 2 : Алтай в конце 1718 в. Барнаул, 2019. С. 76-86.

Р. П. Потапова, кандидат социологических наук Алтайский государственный институт культуры (Барнаул, Россия) raisapotapova@mail.ru

\title{
К ВОПРОСУ О РАЗВИТИИ КОНФЛИКТОЛОГИЧЕСКОЙ ГРАМОТНОСТИ ОБУЧАЮЩИХСЯ НАПРАВЛЕНИЯ «БИБЛИОТЕЧНО-ИНФОРМАЦИОННАЯ ДЕЯТЕЛЬНОСТЬ
}

Аннотация. Низкий уровень конфликтологической грамотности населения не позволяет эффективно управлять социальными конфликтами. Конфликтологическая грамотность является частью общей культуры личности и включает, прежде всего, навыки конструктивного поведения в конфликте и владение основами конфликтологических знаний и умений. Тренинг является важнейшим средством и условием развития конфликтологической грамотности личности обучающегося в образовательном процессе вуза.

Ключевые слова: сочиальный конфликт, конфликтология, конфликтологическая грамотность, тренинг, управление конфликтами, образование, библиотечно-информационная деятельность.

Конфликты являются типичной формой взаимодействия различных субъектов. В качестве таковых выступают отдельные индивиды, группы людей, социальные институты, то есть разнообразные формы социальности. В последние годы отмечен стихийный рост конфликтов в различных сферах общественной жизни.

О высоком уровне конфликтности населения Алтайского края демонстрируют результаты социологического исследования, проведенного в рамках проекта «Рейтинг социальной напряженности в регионах России». Анализируя получен- 
ные в ходе исследования данные, В. В. Нагайцев справедливо констатирует, что конфликт - это неустранимый тип социального взаимодействия, а противоречия в целях и интересах социальных субъектов неискоренимы. Признание «нормальности» социального конфликта расширяет и углубляет проблему работы с ним [1].

Эффективному регулированию конфликтами препятствует низкая конфликтологическая грамотность населения. Решение этой проблемы и производных от нее - обязательное условие развития конфликтологии.

Конфликтологическая грамотность личности - это сложносоставное качество человека, включающее в себя, как считает В. В. Нагайцев, следующие элементы: конфликтоустойчивость человека; конфликтоспособность личности; навыки конструктивного поведения в конфликте; владение основами конфликтологических знаний и умений [1]. Конфликтологическая грамотность является частью общей культуры личности. Умение регулировать свои отношения с другими людьми в конфликтной ситуации, контролировать свое поведение и поведение своего оппонента; способность противостоять манипуляциям и провокациям ложных конфликтов предопределяет успешность представителей любой профессии, непосредственно работающими с конфликтогенными людьми, и библиотекари не исключение.

Мониторинг профессиональной деятельности специалистов в области информационных ресурсов давно требовал применения в образовательном процессе методов обучения, направленных на развитие конфликтологической грамотности у обучаемых. Более того, успешное развитие обучающих программ, вовлекающих каждого бакалавра по направлению «Библиотечно-информационная деятельность» в мыслительную и поведенческую активность, отдельных вузов дает основание говорить о тренинговых формах обучения в контексте повышения качества образования в сфере культуры и искусства и развития конфликтологической грамотности.

Тренинг является важнейшим средством развития конфликтологической грамотности личности обучающегося в образовательном процессе Алтайского государственного института культуры. Тренинговые упражнения в рамках курса «Конфликтология» нацелены не только на формирование научно-обоснованного представление о природе конфликта, но и на развитие способности адекватного реагирования на разного рода конфликтные ситуации.

У большинства обучающихся, которые только начинают изучать конфликтологию, слово «конфликт» вызывает достаточно негативные ассоциа- ции (скандал, ссора, склока и т. д.) и эмоции, (агрессия, зависть, злоба, апатия и т. п.). Анализ ответов студентов на первом занятии (в рамках задания составления банка эмоций, которые вызывает конфликт) дает основание этот факт зафиксировать и обратить на него внимание обучающихся.

Тренинг дозволяет диагностировать взаимоотношения в группе, закреплять теоретический материал, представленный на лекционном занятии. Выполнение тренинговых упражнений позволяет решать следующие задачи в рамках учебного процесса: отработать навыки: сотрудничества с другими при выполнении общего задания, планирования своих действий, оценивания полученного результата, выбора наилучшего варианта решения поставленного вопроса, самоорганизовываться и т. д. Студенты через совместную деятельность взаимопроникают в интересы друг друга, оценивают себя и могут освоить техники, снижающие напряжения в группе. Эту задачу отчасти решает одно из тренинговых заданий по написанию комплиментов (себе, одногруппникам). Данное задание способствует определению значимости партнера, его мнения; предоставляет возможность акцентировать внимание на общности интересов и мнений обучающихся. В ходе тренинга обучающийся овладевает навыками достойного реагирования на критику и закрепляет правила комплементарности.

Очевидный интерес вызывает у студентов задание обосновать, какие из предложенных утверждений о конфликтах истинные, а какие ложные. Данное задание базируется на аргументации своего выбора. При выполнении задания студенты демонстрируют уровень конфликтологической подготовки, проявляющийся в житейском интуитивном опыте, мифологическом сознании личности. Именно практические конфликтологические знания, как правило, определяют, какую стратегию поведения выберет человек в конкретном конфликте. Безусловно, народная мудрость, связанная с опытом поведения в межличностных конфликтах, аккумулируется в пословицах, поговорках. Достаточно вспомнить многочисленные поговорки и фразеологизмы: «Лучшая защита это нападение», «Первый удар - половина боя», «Хорошо богатство, а согласие лучше», «Пан или пропал», «Что за шум, а драки нет?»; «Полно браниться, не пора ль мириться?»; «Не рой людям яму, сам свалишься»; «Отольются кошке мышкины слезы», «Либо грудь в крестах, либо голова в кустах», «Сколько не мучиться, а без ссоры не прожить» и т. д. Именно этим предопределено задание дать конфликтологическую оценку поговорок и пословиц. На их примере можно рассмотреть постулаты конфликтологии, стратегии и 
тактики поведения оппонентов в конфликте, и даже методики устранения конфликтов.

В конфликтологических тренингах часто используются тестовые методики. Посредством тестирования осуществляется попытка вывести обучающихся на самооценку по показателям внутриличностного и межличностного конфликта. Например, тест В. Коулмана направлен на определение наличия внутриличностного конфликта; тест К. Леонгарда-Г. Шмишека позволяет выявить чрезмерность проявления некоторых черт характера или их сочетаний. Тест К. Томаса объективно выявляет тенденции поведенческого проявления в конфликте: соперничество, сотрудничество, компромисс, избегание или приспособление [2]. При этом, выбор стратегий поведения в конфликтах является одним из критериев развития конфликтологической культуры личности обучающегося наряду с конфликтологической компетентностью, эмоциональный интеллектом, уровнем конфликтности личности.

Конфликтологическую культуру обучающегося можно рассматривать как совокупность познавательных способностей и личностных характеристик, определяющих верное восприятие конфликта и позволяющих разумно регулировать конфликт. Использование тестовых форм в учебном процессе содействует пониманию и принятию того факта, что нет «плохих» или «хороших» черт характера, но есть личностные характеристики конфликтологической направленности.

Задания по форме «Приведите известный пример конфликта из истории, литературы или кино» при характеристике видового разнообразия конфликтов активизирует интерес к произведениям художественной литературе, что расширяет грани формирования ключевых компетенций учащихся. Изучение проблемы анализа и диагностики конфликтов подразумевает обращение к произведениям художественной литературы. Первоначально отработав навыки на уже известных, описанных конфликтах, студентам легче осуществлять анализ личных конфликтов.

Вектор применения художественной литературы при изучении конфликтологии задан доктором социологических наук, профессором Р. А. Трофимовой. Р. А. Трофимова подготовила цикл статей о конфликтологических загадках в рассказах А. П. Чехова. В публикациях Р. А. Трофимовой поднят вопрос о значении художественнообразного осмысления конфликтов, образец которому дал А. П. Чехов; представлены существеннозначимые характеристики противодействий социальных субъектов на примере рассказа «Новая дача» (конфликт между крестьянами деревни Обручановой и семьей инженера Кучерова), повести
«Дуэль» (конфронтация ученого фон Корена с чиновником Лаевским), рассказа «Неприятность» (конфликт между земским врачом и его помощником - фельдшером), рассказа «Душечка». Анализируя последнее произведение, автор затрагивает вопрос об оптимальных рамках конфликтогенности и конфликтности человека вообще, женщины и супруги, в частности, который конфликтологией еще не решен. Р. А. Трофимова считает, что в конфликтологическом перепрочтении нуждается большинство произведений А. П. Чехова, в том числе, так называемые психиатрические («Палата №6», «Черный монах»), психологические («Скучная история», «Учитель словесности», «В усадьбе», «Соседи» и др.) и семейные («Страх», «Именины», «Попрыгунья», «Жена») рассказы, а также все его пьесы. В них тоже поставлены задачи, до сих пор не решенные наукой о конфликтах $[3,4]$.

Следует признать и наличие объективных причин сложности выполнения тренинговых заданий. Они связаны с практическим функционированием образовательного пространства, прежде всего - это малочисленные студенческие группы, характерные для очной формы обучения.

В результате тренинговых занятий в рамках дисциплины «Конфликтология» обучающиеся по направлению «Библиотечно-информационная деятельность» приобретают знания, умения, соответствующие профессиональной компетенции специалиста: применение инфокоммуникационных технологий, принятию профессиональных решений и т. д.

Конфликтологическая грамотность менеджеров информационных ресурсов высшей квалификации развивается не только в рамках дисциплины «Конфликтология», но и таких курсов как «Управление персоналом библиотеки», «Менеджмент библиотечно-информационной деятельности». Это связано с тем, что особое значение придается организационным (управленческим) конфликтам. Возникновение и проистекание этих конфликтов нарушает нормальный ход процесса управления, как правило, снижает результативность и качество деятельности отдельных коллективов. По мнению Денисова О. И., конфликтологическая грамотность руководителя входит в структуру профессионализма личности [5].

Современным специалистам в библиотечноинформационной сфере нужны знания, навыки решения конфликтных ситуаций. Об этом официально заявили руководители библиотек Алтайского края в рамках круглого стола по теме: «Опыт и проблемы подготовки специалистов по направлению «Библиотечно-информационная деятельность» в контексте обсуждения оснований, возможностей и перспектив подготовки специалистов 
по направлению «Библиотечно-информационная деятельность», проведенного на базе Алтайского государственного института культуры 5 февраля 2020 года. В ходе обсуждения неоднократно акцентировалось внимание участников на проблеме многофункциональности библиотечной профессии, исходя из этого, о необходимости углубленной подготовки обучающихся по многим направлениям, и в том числе коммуникационным технологиям. В муниципальных, вузовских библиотеках в современных реалиях должна быть взаимозаменяемость специалистов. В этих условиях важно, чтобы библиотекари - выпускники вуза могли себя самопрезентовать, обладали навыками позиционирования себя в коллективе. Конфликтологическая грамотность, информационная компетентность, умение работать в условиях многозадачности - это не весь, но ключевой перечень современных требований работодателей к выпускникам вузов.

В целом следует отметить, что развитие конфликтологической грамотности бакалавров следует рассматривать как последовательный и происходящий в определенном временном интервале и социально-психологических условиях образовательной среды процесс, обеспечивающий качественно новый уровень межличностного взаимодействия. Представленная тренинговая модель развития конфликтологической грамотности обучающихся может быть применена при создании специализированных обучающих семинаровтренингов.

\section{Список литературы}

1. Нагайщеев В. B. Конфликтологическая грамотность населения региона // Society and Security Insights. 2018. № 1. C. 93-98.

2. Трофимова Р. А., Растов Ю. Е., Нагайцев $B$. B. Конфликтология. Барнаул, 2006. 127 с.

3. Трофимова Р. А. Конфликтологические загадки в рассказах А. П. Чехова // Социальноинформационные ресурсы библиосоциальной работы. Барнаул, 2011. Вып. 12. С. 8-12.

4. Трофимова Р. А., Растов Ю. Е. Конфликтологическая загадка рассказа А. П. Чехова «Новая дача»// Учёные записки. 2010. № 6: Теория и практика исследования социально-культурной деятельности, художественного образования, информ. ресурсов. С. 171-173.

5. Денисов О. И. Развитие конфликтологической компетентности руководителей : автореф. дис. ... канд. психол. наук: 19.00.13. Москва, 2001. URL: https://www.dissercat.com/content/razvitiekonfliktologicheskoi-kompetentnosti-rukovoditelei (24.10.2020). mila_san@mail.ru

\section{АЛТАЙСКАЯ КРАЕВАЯ ДЕТСКАЯ БИБЛИОТЕКА ИМЕНИ Н. К. КРУПСКОЙ: 100 ЛЕТ СЛУЖЕНИЯ ДЕТЯМ И КНИГЕ}

Аннотация. На протяжении века Алтайская краевая детская библиотека им. Н. К. Крупской остается притягательным «третьим» местом для детей и подростков, их родителей и педагогов, детских писателей и иллюстраторов. История библиотеки богата любопытными фактами и событиями, в том числе трогательной перепиской с Н. К. Крупской. Современность библиотеки насыщена интересными проектами и акциями, направленными на продвижение чтения.

Ключевые слова: история библиотеки, дети, продвижение чтения, детские книги, культурнопросветительская деятельность.

Датой основания Алтайской краевой детской библиотеки им. Н. К. Крупской (далее - АКДБ) считается 2 апреля 1920 г. Тогда она была создана как детская библиотека г. Барнаула на базе Зайчанской народно-школьной библиотеки, организованной в апреле 1909 г. Обществом попечения о начальном образовании и носившей имя известно- го просветителя В. К. Штильке.

В июне 1922 г. библиотека стала центральной, она занимала тесное помещение в старом деревянном здании на ул. Интернациональной, 69 (позже 73). В августе на должность заведующей была назначена Анна Савельевна Шуругина.

В Государственном архиве Алтайского края 